\title{
Weight regain among women after metabolic and bariatric surgery: a qualitative study in Brazil
}

\author{
Reganho de peso em mulheres após cirurgia metabólica e bariátrica: \\ estudo qualitativo no Brasil
}

\author{
Ataliba de Carvalho Jr., ${ }^{1}$ Egberto Ribeiro Turato, ${ }^{2}$ Elinton Adami Chaim, ${ }^{3}$ Ronis Magdaleno Jr. ${ }^{4}$
}

\begin{abstract}
Introduction: Due to the increased number of bariatric surgeries over the years, aspects contributing or hindering the achievement of outcomes, among them weight regain, have acquired increased significance. Psychological factors directly influence on this unwanted situation, but there are few studies and controversies about the degree of participation of these factors. We propose a qualitative investigation to analyze the meanings of weight regain after surgery among women and how these factors influence this outcome.

Method: This study uses the clinical-qualitative method, by means of a semi-structured interview with open questions in an intentional sample, closed by saturation, with eight women who underwent surgery at the Bariatric Surgery Outpatient Clinic of Hospital das Clínicas, Universidade Estadual de Campinas (UNICAMP), in the state of São Paulo, Brazil.

Results: A feeling of defeat and failure emerges with weight regain, which contributes to social isolation; there is no regret, but gratitude for the surgery; among patients, there is a sense of feeling rejected greater than a rejection that actually exists. Conclusion: We found out the need for further qualitative studies that help the health team to better understand the dynamic psychological factors involved in the meaning of weight regain after bariatric surgery among women, in order to adopt appropriate conducts to deal with this problem.

Keywords: Obesity, bariatric surgery, weight regain, qualitative method, morbid obesity.
\end{abstract}

\section{Resumo}

Introdução: Com o aumento do número de cirurgias bariátricas ao longo dos anos, têm chamado atenção os aspectos que contribuem ou impedem os resultados, entre eles o reganho de peso, mostram-se relevantes. Fatores psicológicos influenciam diretamente essa situação indesejada, mas há poucos estudos e controvérsias sobre o grau de participação desses fatores. Nós propomos uma investigação qualitativa para analisar os significados do reganho de peso depois da cirurgia para mulheres e como esses fatores influenciam esse resultado.

Método: Este estudo usa o método clínico-qualitativo, por meio de entrevista semiestruturada com questões abertas em uma amostra intencional, fechada por saturação, com oito mulheres operadas no ambulatório de cirurgia bariátrica do Hospital das Clínicas da Universidade Estadual de Campinas (UNICAMP), no estado de São Paulo.

Resultados: Um sentimento de derrota e fracasso surge com o reganho de peso, que colabora para o isolamento social; não há arrependimento, mas gratidão pela cirurgia; entre as pacientes, há uma ideia de sentir-se rejeitada maior que uma rejeição que existe de fato.

Conclusão: Constatamos a necessidade de novos estudos qualitativos que auxiliem a equipe de saúde a entender melhor os fatores psicológicos dinâmicos envolvidos no significado do reganho de peso após a cirurgia bariátrica entre as mulheres para adotar condutas adequadas para lidar com esse problema. Descritores: Obesidade, cirurgia bariátrica, reganho de peso, método qualitativo, obesidade mórbida.

\footnotetext{
${ }^{1}$ Graduate Program in Medical Sciences, Department of Medical Psychology and Psychiatry, School of Medical Sciences, Universidade Estadual de Campinas (UNICAMP), Campinas, SP, Brazil. ${ }^{2}$ Head, Laboratory of Clinical-Qualitative Research, Department of Medical Psychology and Psychiatry, School of Medical Sciences, UNICAMP, Campinas, SP, Brazil. ${ }^{3}$ Department of Surgery, School of Medical Sciences, UNICAMP, Campinas, SP, Brazil. ${ }^{4}$ Researcher, Laboratory of Clinical-Qualitative Research, Department of Medical Psychology and Psychiatry, School of Medical Sciences, UNICAMP, Campinas, SP, Brazil.

This article was based on the first author's dissertation, entitled "Life experiences of patients with weight regain after metabolic and bariatric surgery: a clinical-qualitative study" ("Vivências emocionais de pacientes submetidos à cirurgia metabólica e bariátrica com reganho de peso: um estudo clínico-qualitativo"), presented on January 25, 2013, at Universidade Estadual de Campinas (UNICAMP), Campinas, SP, Brazil. Financial support: none.

Submitted Sep 07 2013, accepted for publication Apr 22 2014. No conflicts of interest declared concerning the publication of this article. Suggested citation: Carvalho Jr A, Turato ER, Chaim EA, Magdaleno Jr R. Weight regain among women after metabolic and bariatric surgery: a qualitative study in Brazil. Trends Psychiatry Psychother. 2014;36(3):140-146. http://dx.doi.org/10.1590/2237-6089-2013-0041
} 


\section{Introduction}

Obesity is a growing public health problem all over the world. ${ }^{1,2}$ In Brazil, just as in the rest of the world, obesity has reached epidemic proportions. ${ }^{3,4}$ In addition to the increased prevalence of obesity, failure of the conventional treatment has led to an increased number of metabolic and bariatric surgeries (MBS), ${ }^{5}$ albeit not at the same speed over the last 5 years. ${ }^{6}$

After surgery, long-term weight loss maintenance is not a guaranteed outcome, ${ }^{7,8}$ its success depends on significant behavioral changes, as well as on the ability to reduce the use of food as a means to fulfill emotional needs. ${ }^{9-15}$ A significant number of patients has an early cessation of weight loss or weight regain after metabolic and bariatric surgery (WRMBS), ${ }^{16}$ with eating disorders, such as the onset or recurrence of eating compulsion. ${ }^{17}$ The issue of patient's emotional state on regaining weight after MBS, as well as surgery itself, ${ }^{13,18,19}$ still remains a controversial and poorly studied theme. We believe it is crucial to know the psychosocial factors involved in the evolution of these patients. Regaining weight negatively interferes with psychosocial aspects and the clinical evolution of patients. ${ }^{12,20,21}$ Among the factors posing a risk for weight regain there are history of weight cycling, recent weight losses, major weight losses, high depression levels, disinhibited eating, binge eating, increased hunger, lack of control over food urges, eating in response to negative emotions and stress, passive reactions to problems, and concerns over addictive behaviors. ${ }^{12,20,21}$

Gaining weight after surgery is felt as a double failure: becoming obese in the first place, and not fulfilling the expectations of keeping weight under control, despite having had the surgery. ${ }^{22}$ Weight regain is associated with feelings of shame and defeat. Despite the confidence seen in most patients and the fact that their digestive system is surgically altered to prevent relapse, most struggle to maintain weight loss. ${ }^{23}$

Research shows that WRMBS is expected and this fact is related to readaptation of eating habits and increased caloric intake. $7,24,25$

Weight regain has a significant impact on the lives of some patients who undergo MBS and feel as if they had failed. The phenomenon has been explained in terms of both the mechanics of the operation and the participants' "cheating" attempts, as they continue to use food for emotional regulation. ${ }^{26}$ Weight regain is connected to with emotional distress, shame, and self-contempt. ${ }^{23}$ The patients' behavior and their relationship with food usually change after the surgery, resulting from an improved sense of control over what to eat and how to feel about food. ${ }^{26}$ Patients describe their experience in terms of the impact of surgery on eating behaviors and on their health status, reflecting, respectively, their relationships with food and with other people. ${ }^{27}$ Odom et al. argue about how little we know about these consequences and about the difficulties generated by the failure in patient follow-up. ${ }^{21}$

The objective of this study was to assess the emotional significance, for women, of regaining weight after MBS.

\section{Subjects and method}

This study has a clinical-qualitative design, which is a specific form of the qualitative method applied to the health field and allows analyzing life experiences and suffering related to a given problem in the health-illness process. This is a graduate study conducted at Universidade Estadual de Campinas (UNICAMP), in the state of São Paulo, Brazil.

Thus, this constitutes an adaptation of the humanistic method, which seeks to interpret scientifically the meanings that individual life experiences acquire. ${ }^{28}$

Qualitative research analyzes things at their natural settings, in an attempt to interpret the phenomenon in terms of meanings that people attribute to them. We believe that the application of a qualitative method is extremely useful for physicians, as it allows them to understand clinical phenomena observed during their practice. ${ }^{28-32}$

The tool used for gathering data was a semistructured interview with open questions ${ }^{33}$ applied to an intentional sample, i.e. this study was carried out with a small number of people, chosen deliberately due to the importance they have regarding a given theme and according to their social representation. ${ }^{28,30,33}$

This approach aims to guarantee that the problems are discussed in depth with respondents. The technique adopted to gather the sample in a qualitative research meets the need of using a statistical representation of the population under study, i.e. random studies are not used. Data is produced with the aid of reformulating, changing, complementing, and/or clarifying initial hypotheses.

The sample consists of eight women who had regained weight after surgery at the Bariatric Surgery Outpatient Clinic of Hospital das Clínicas, UNICAMP, a tertiary public university hospital in the city of Campinas, São Paulo, in the south-eastern region of Brazil. The interval between the surgery and the interview ranged from 3.5 to 11 years, with an average of 9 years (Table 1 ). The interviews were conducted between September 2010 and January 2011. The length of time between the lowest post-surgery weight and the onset of weight regain ranged from 15 to 36 months, with an average of 23 months. ${ }^{7,34,35}$ A significant weight regain was defined as $\geq 15 \%$ of the lowest weight achieved after surgery ${ }^{21}$; the patient with the lowest value had $22 \%$ of regain of the lost weight and the highest value in this regard was 54\% (Table 2, Figures 1 and 2). 
Table 1 - Demographic characteristics of the sample

\begin{tabular}{lcccccc}
\hline Patient no. & Marital status & Education level & Occupation & Religion & Number of children & Time since surgery \\
\hline P1 & Married & Elementary School & Housewife & Catholic & Two & $11 \mathrm{y} 3 \mathrm{~m}$ \\
P2 & Single & High School & Pensioner & Catholic & None & $3 \mathrm{y} 5 \mathrm{~m}$ \\
P3 & Married & High School & Pensioner & Catholic & Two & $11 \mathrm{y} 11 \mathrm{~m} *$ \\
P4 & Widow & High School & Pensioner & Protestant & One & $10 \mathrm{y} 8 \mathrm{m*}$ \\
P5 & Single & Higher Education & Public official & Spiritualist & One & $10 \mathrm{y} 10 \mathrm{~m}$ \\
P6 & Married & Elementary School & Housewife & Catholic & Three & $5 \mathrm{y} 7 \mathrm{~m}$ \\
P7 & Married & High School & Public official & Catholic & Two & $8 \mathrm{y} 5 \mathrm{~m}$ \\
P8 & Divorced & Elementary School & Public official & Catholic & Two & $10 \mathrm{y} 8 \mathrm{~m}$ \\
\hline
\end{tabular}

$\mathrm{m}=$ month; $\mathrm{P}=$ patient; $\mathrm{y}=$ year

* P3 and P4 were submitted to biliary-pancreatic derivation (Scopinaro procedure), 3 and 2 years after the gastric by-pass Roux-en-Y, respectively. All respondents were from the metropolitan area of Campinas or nearby.

The sample was closed using the saturation criteria, ${ }^{36}$ i.e., when the addition of new interviews could add very little information regarding the initial aims. The interviews were recorded with patients' consent. The first question was: "Tell me a little about how you feel when you realize that you regained weight after bariatric and metabolic surgery." Based on the answer to this question, 10 previously prepared questions were asked, not necessarily in the order indicated below; whenever considered adequate, the researcher could change them, in order to make them fit for the specific situation. The 10 previously prepared questions were:

1) Right after the surgery, have you feared or fantasized regaining weight?

2) What do you think caused you to regain weight?

3) Do you attribute this condition to emotional distress or any other thing important to you?

4) Have you had any recurrent dream? Tell me any one you remember from the last months.

5) How do you feel about yourself concerning the fact that you are regaining weight?

6) What do you believe people think about you regarding the fact of regaining weight after the surgery?

7) What do you believe people close to you, those who follow your history since you decided to undergo surgery, think about you today?

8) What was the most remarkable fact in your life since you started regaining weight after the surgery?

9) What are you going to do now?

10) Is there any other important thing you would like to tell me about the fact of regaining weight after the surgery?

The eight semi-structured interviews lasted between 80 and 100 minutes, with an average of 85 minutes per interview. The interviews were conducted in Portuguese, and the excerpts used in the present study were freely translated into English. We tried to create a neutral, friendly, and kind environment, besides avoiding to ask questions that could induce answers.

The transcript of interviews made up the corpus of this study, providing data for the qualitative analysis. ${ }^{37}$ This did not infer categories based on the frequency of modules or units (or other mathematical approach). Thus, the phenomenon may be interpreted as a shared concept, which can be generalized in other environments.

The results were validated by peer review conducted by the team from the Laboratory of Clinical-Qualitative Research, Department of Medical Psychology and Psychiatry, School of Medical Sciences, UNICAMP.

Table 2 - Clinical characteristics of the sample

\begin{tabular}{|c|c|c|c|c|c|}
\hline Patient no. & Age (years) & Weight at surgery (BMI) & Lowest weight (BMI) & Current weight (BMI) & Weight regain \\
\hline P1 & 56 & $165(59.9)$ & $93(33.7)$ & $125(45.4)$ & $32(44)$ \\
\hline P2 & 38 & $115(44.9)$ & $88(34.4)$ & $102(39.8)$ & $14(48)$ \\
\hline P3 & 55 & $140(46.2)$ & $92(30.9)$ & $118(38)$ & $26(54)$ \\
\hline P4 & 40 & $188(73.4)$ & $114(44.5)$ & $133(51)$ & $19(25)$ \\
\hline P5 & 42 & $159(58.4)$ & $75(27.5)$ & $127(46.6)$ & $32(38)$ \\
\hline P5 & 55 & $118(50.4)$ & $65(27.8)$ & $77(32.9)$ & $12(22)$ \\
\hline P7 & 61 & $130(56.3)$ & $91(39.4)$ & $108(46.7)$ & $17(43)$ \\
\hline P8 & 41 & $110(51.6)$ & $62(29.1)$ & $77(36.1)$ & $15(31)$ \\
\hline
\end{tabular}

Data expressed as $\mathrm{kg}(\%)$

$\mathrm{BMI}=$ body mass index; $\mathrm{P}=$ patient. 
This study was approved by the Research Ethics Committee of the Medical School of UNICAMP.

\section{Results}

We identified four categories: 1) weight regain: defeat and failure; 2) absence of regret and certainty of success; 3) experience of abandonment; and 4) loss of self-esteem: risk of social isolation. Each category is described below.

\section{Weight regain: defeat and failure}

After the surgery, I was happy. I thought I had won life. I walked, I bought jeans, I felt like getting dressed up. (P1)

The experience of losing weight after the surgery is a landmark in the lives of patients who have undergone MBS. ${ }^{38-41}$ The most significant gains are: experience of social reintegration and acceptance ${ }^{40}$; recovery of the quality of life $\mathrm{e}^{9,25,42}$; reduced feelings of sadness and anxiety ${ }^{43}$; and improved self-esteem. ${ }^{40}$ Regaining weight is experienced as a significant loss, it gives rise to feelings of defeat and failure. The advantages of weight loss, regarded as triumphs, fade away and a feeling of devitalization may have dire effects on women who face a permanent challenge in order to remain motivated, both to keep their weight and comply with the continued clinical care needed after surgery. This motivation decreases as they start feeling to be "losing the battle" against obesity, something which stimulates them to to use food as a compensation for frustration again.

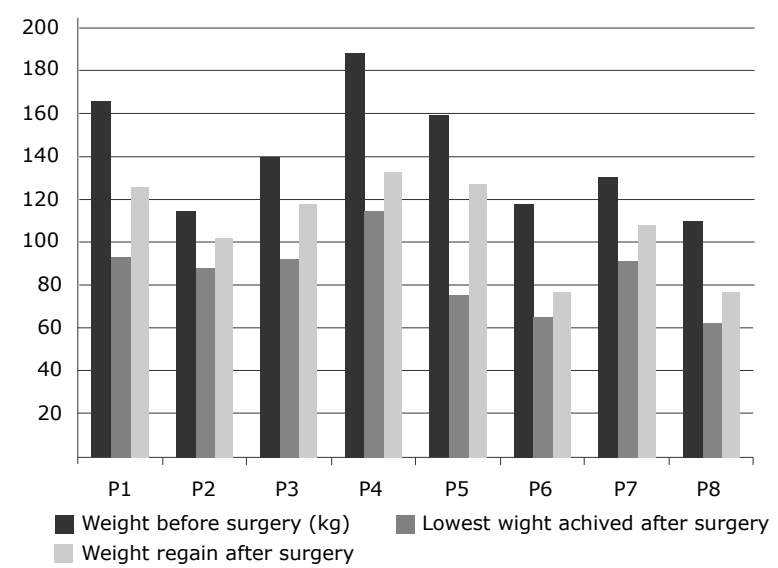

Figure 1 - Weight variations of each patient before surgery, with the lowest weight achieved after surgery and the weight regained after surgery.

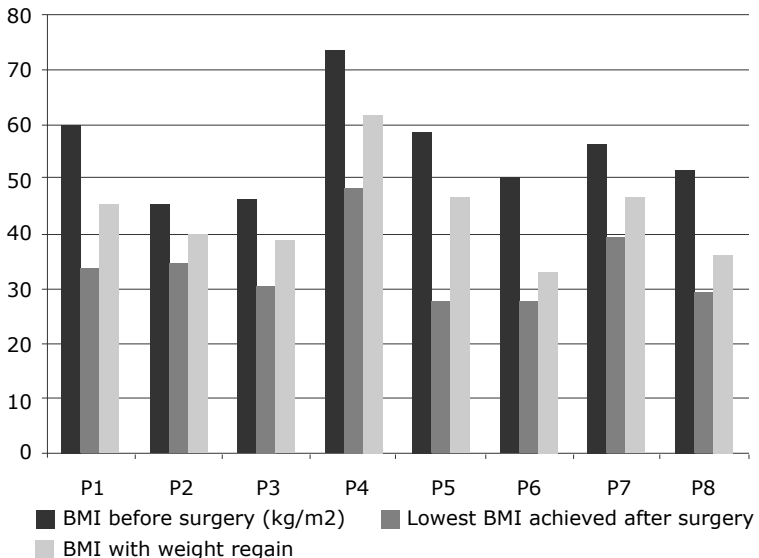

Figure 2 - Variations in BMI of each patient before surgery, with the lowest BMI achieved after surgery and the regained BMI after surgery. BMI = body mass index.

After I started regaining weight, [things] started to fade, I did not want to leave home anymore, I got dressed up, put on lipstick, or dyed my hair. I started wilting... (P1)

Her life, which had begun to acquire new colors, began to fade, to wilt, and this feeling of disillusion is intense. Due to weight regain, the achievements of the surgery become meaningless, but there still remain good memories of the experience and the benefits obtained, to such an extent that many patients want to repeat the surgical procedure. ${ }^{25}$

Today, I may attribute to the surgery the fact that I am here, alive, and I would undergo the surgery again if needed... (P4)

\section{Absence of regret and certainty of success}

Even with weight regain, these women feel their expectations, vis-à-vis the surgery, were met, they are grateful to the health team and show no regret. There is a firm belief that the surgery was a good choice.

We undergo surgery, which is not an easy thing to do, but I do not regret it a bit... (P5)

Despite all the damage associated with weight regain, the patients are grateful for the opportunity to undergo surgery and for other gains, above all for having received effective help to fight the chronic problem of obesity and its complications, against which they have been struggling for most of their lives.

Even putting on weight and becoming sad, I am not criticizing the surgery, I think it was a great help... (P1) 


\section{Experience of abandonment}

[...] the comment I hear is that "they" are not going to like it. I can even understand that they do not like it. I shall have to answer to it. I only hope it is done as gently as possible... (P7)

An unrealistic expectation about the results of MBS and weight loss is a frequent occurrence. ${ }^{40}$ The patients who regain weight regain weight feel that, somehow, they have betrayed the trust of those who gave them a chance to lose weight. The feeling of defeat and failure may drive them away from the health care service, due to fear of not being welcome and not being understood by the health team.

We felt a little abandoned... they paid more attention to the "pre-op" than to the "post-op." It is not just me who thinks this way; other friends feel the same... (P1)

Somehow, they feel to be special patients, different from the other obese women who did not choose to undergo surgical treatment, and this could demand a special sort of alliance with the team treating them. Weight regain could be experienced as breaking this alliance, thus turning a woman into a problem patient, with powerful fantasies of rejection. The situation becomes complicated when there is any kind of criticism by the team, when weight regain is regarded as a failure of the patient.

Those of us who undergo surgery, I am not saying we are ETs, but we are different from other people. $A$ common person is not going to understand this... (P4)

\section{Loss of self-esteem: risk of social isolation}

[...] everything bothers [us]! Let us suppose this: you want to use a dress and it does not look good, thus, well! What may I say? It also influences on our self-esteem! (P8)

The feelings of defeat and failure bring up a loss of self-esteem that can lead to social isolation. Weight regain, if persistent, is accompanied by a loss in quality of life due to low self-esteem, which emerges along with it. When they realize the impossibility of controlling weight, even after MBS, leads the self-esteem of these women to drop still further, then, they use it as a reason to get away from people who might criticize them.

[...] it is difficult to admit it, but I feel like this, I realize that it was because of this that I began to withdraw. I have withdrawn from things, because
I am unhappy about myself, because it has been a struggle all my life. (P7)

There is a fear they are going to have to answer to questions about their weight, something which leads them to a sticking point, because they have already arrived at the last stage of their battle against obesity, i.e. MBS, but the problem still remains. And they have lost control again.

I am really sad, and people ask: why do not you undergo the stomach reduction surgery? Then, you think: but I have undergone it! And so, what? It is complicated! (P4)

\section{Discussion}

Regaining weight after MBS is a complex psychological situation. There is, at the same time, a feeling of defeat and failure, as well as the memory of a positive experience, regarding an improved quality of life and a healthy weight. It is important that the health team is aware of the previous positive experiences, in order to be able to define conducts that use these positive experiences to deal with the current problem of WRMBS. A patient who has regained weight after MBS, unlike an obese counterpart who has not undergone surgery, has an actual experience of weight loss, which is a distinctive feature for subsequent treatment, with a view to resume a healthy weight after weight regain.

Therefore, there is a profound, positive mark in operated women who regain weight after a successful period, leading to the need to carefully take into consideration how intense the impact of weight regain can be. These patients deeply need the kind of help that the surgery provides. The absence of regret seen among weight regain complaints may reflect the importance of this aspect. Defeat, failure, renunciation, low selfesteem, and isolation may oppose to the absence of regret. This may be a powerful aspect, and the health team can synergistically act on it by contributing to maintain follow-up and restoring contact with those who abandon clinical treatment.

Considering these patients victorious, with a potential to constantly fight obesity, is a positive attitude against the idea of failure usually associated with the morbidly obese who have undergone surgery and regained weight. These patients have been through a complex procedure, which included risk of death, but regained weight. We question whether healthy, non-obese people can reach this level of understanding. 
Conversely, and maybe less significantly, these patients tend to feel anxious, excluded, and discriminated. A new vicious circle involving low self-esteem, anxiety, and increased hunger ${ }^{40}$ is established, i.e. lower selfesteem leads to social isolation and a tendency to quit medical care. Understanding this phenomenon makes us aware of the need for active attitudes taken by the health team in order to seek the patients who, to avoid criticism, voluntarily get away from the health care service. Thus, the vicious circle is complete: the greater the weight regain, the greater the need for help, fear of criticism, and treatment dropout, as well as weight increase. The risk is that these patients who regain most of their weight after surgery are precisely those who does not comply with post-operative care for MBS, with more complications and a worse prognosis as a consequence.

We think that this group of patients shows a psychological state marked by an exacerbated sensitivity to criticism, which easily leads them to get away from the health care service and quit both clinical and psychological care. Thus, the health team must be prepared to deal with the complex psychosocial fabric of this group of patients and propose active strategies to seek them with a view to resume medical, psychological, and nutritional care.

There is current trend with a growing interest in conceptualizing obesity as "food addiction." It is important that health professionals identify individuals who may require a specific approach that incorporates techniques used to treat addictions. The clinical significance of this association is unknown and it needs to be validated by further studies. ${ }^{44-47}$

The literature on weight regain after MBS shows difficulties over patient's follow up. We may ask if people with significant weight regain are more likely to treatment dropout. Another delicate issue is that people with weight regain after surgery tend to underestimate their intake and overestimate their physical activity. ${ }^{20,21}$

We believe that, by using a qualitative method of scientific research, we may get closer to determine the subjective significance attributed to the experience by this group of patients. Nevertheless, it is a complex pathway and we inevitably have to restrict our conclusions to some categories identified by the researcher. Therefore, other possibilities should remain open for further qualitative studies.

\section{References}

1. Buchwald H, Williams SE. Bariatric surgery worldwide 2003. Obes Surg. 2004;14:1157-64.

2. World Health Organization. Obesity and overweight, 2013. http:// www.who.int/mediacentre/factsheets/fs311/en/. Accessed 2013 Aug 07.
3. Ferreira VA, Magalhaes R. Obesidade no Brasil: tendências atuais. Rev Port Sau Pub. 2006;24:71-81.

4. Monteiro CA, Conde WL, Popkin BM. Income-specific trends in obesity in Brazil: 1975-2003. Am J Public Health. 2007;97:180812. Epub 2007 Aug 29.

5. Buchwald $\mathrm{H}$, Consensus Conference Panel. Consensus conference statement bariatric surgery for morbid obesity: health implications for patients, health professionals, and third-party payers. Surg Obes Relat Dis. 2005;1:371-81.

6. Buchwald $H$, Oien DM. Metabolic/bariatric surgery Worldwide 2008. Obes Surg. 2009;19:1605-11.

7. Hsu LK, Benotti PN, Dwyer J, Roberts SB, Saltzman E, Shikora S, et al. Nonsurgical factors that influence the outcome of bariatric surgery: a review. Psychosom Med. 1998;60:338-46.

8. Magro DO, Geloneze B, Delfini R, Pareja BC, Callejas F, Pareja JC. Long-term weight regain after gastric bypass: a 5 -year prospective study. Obes Surg. 2008;18:648-51. Epub 2008 Apr 8.

9. Dymek MP, le Grange D, Neven K, Alverdy J. Quality of life and psychosocial adjustment in patients after Roux-en-Y gastric bypass: a brief report. Obes Surg. 2001;11:32-9.

10. Bocchieri LE, Meana M, Fisher BL. A review of psychosocial outcomes of surgery for morbid obesity. J Psychosom Res. 2002; 52:155-65.

11. Byrne S, Cooper Z, Fairburn C. Weight maintenance and relapse in obesity: a qualitative study. Int J Obes Relat Metab Disord. 2003;27:955-62.

12. Elfhag $\mathrm{K}$, Rössner $\mathrm{S}$. Who succeeds in maintaining weight loss? A conceptual review of factors associated with weight loss maintenance and weight regain. Obes Rev. 2005;6:67-85.

13. Dziurowicz-Kozlowska $A H$, Wierzbicki $Z$, Lisik W, Wasiak $D$, Kosieradzki M. The objective of psychological evaluation in the process of qualifying candidates for bariatric surgery. Obes Surg. 2006;16:196-202

14. Magdaleno Jr. R, Chaim EA, Turato ER. Características psicológicas de pacientes submetidos a cirurgia bariátrica. Rev Psiquiatr RS. 2009;31:73-8.

15. Magdaleno Jr. R, Chaim EA, Turato ER. Surgical treatment of obesity: some considerations on the transformations of the eating impulse. Rev Latinoam Psicopat Fund. 2010;13:425-40.

16. Benotti PN, Forse RA. The role of gastric surgery in the multidisciplinary management of severe obesity. Am J Surg. 1995; 169:361-7.

17. Kalarchian MA, Marcus MD, Wilson GT, Labouvie EW, Brolin RE, LaMarca LB. Binge eating among gastric bypass patients at longterm follow-up. Obes Surg. 2002;12:270-5.

18. Glinski J, Wetzler S, Goodman E. The psychology of gastric bypass surgery. Obes Surg. 2001;11:581-8.

19. Bauchowitz AU, Gonder-Frederick LA, Olbrisch ME, Azarbad L, Ryee MY, Woodson M. Psychosocial evaluation of bariatric surgery candidates: a survey of present practices. Psychosom Med. 2005;67:825-32.

20. McGuire MT, Wing RR, Klem ML, Lang W, Hill JO. What predicts weight regain in a group of successful weight losers? ] Consult Clin Psychol. 1999;67:177-85.

21. Odom J, Zalesin KC, Washington TL, Miller WW, Hakmeh B, Zaremba $\mathrm{DL}$, et al. Behavioral predictors of weight regain after bariatric surgery. Obes Surg. 2010;20:349-56. Epub 2009 Jun 25.

22. Groven KS, Råheim M, Engelsrud G. "My quality of life is worse compared to my earlier life": living with chronic problems after weight loss surgery. Int J Qual Stud Health Well-being. 2010;5:10.3402/qhw.v5i4.5553.

23. Natvik E, Gjengedal E, Raheim M. Totally changed, yet still the same: patients' lived experiences 5 years beyond bariatric surgery. Qual Health Res. 2013;23:1202-14.

24. Sugerman HJ, Kellum JM, Engle KM, Wolfe L, Starkey JV, Birkenhauer R, et al. Gastric bypass for treating severe obesity. Am J Clin Nutr. 1992;55:560S-6S.

25. Myers VH, Adams CE, Barbera BL, Brantley PJ. Medical and psychosocial outcomes of laparoscopic Roux-en-Y gastric bypass: cross-sectional findings at 4 -year follow-up. Obes Surg. 2012;22:230-9.

26. Ogden, J, Sian A, Ellis G. Negotiating control: patients' experiences of unsuccessful weight-loss surgery. Psychol Health. 2006;21:273-93.

27. Ogden J, Clementi C, Aylwin S. The impact of obesity surgery and the paradox of control: A qualitative study. Psychol Health. 2006;21:273-93.

28. Turato ER. Tratado da Metodologia da Pesquisa Clínico-Qualitativa: construção teórico-epistemológica, discussão comparada e aplicação nas áreas da saúde e humanas. 4a ed. Petrópolis: Vozes; 2010. 
29. Denzin NK, Lincoln YS. The SAGE handbook of qualitative research. 3rd ed. Thousand Oaks: Sage Publications; 2005.

30. Minayo MCS. O desafio do conhecimento-pesquisa qualitativa em saúde. $12^{a}$ ed. São Paulo: Hucitec; 2010.

31. Morse JM, Field PA. Qualitative research methods for health professionals. 2nd ed. London: Sage Publications; 1995.

32. Patton MQ. Qualitative evaluation and research methods. London: Sage Publications; 1990.

33. Fontanella BJ, Campos CJ, Turato ER. Data collection in clinicalqualitative research: use of non-directed interviews with open-ended questions by health professionals. Rev Lat Am Enfermagem. 2006;14:812-20.

34. Shamblin JR, Shamblin WR. Bariatric surgery should be more widely accepted. South Med J. 1987;80:861-5.

35. Powers PS, Rosemurgy A, Boyd F, Perez A. Outcome of gastric restriction procedures: weight, psychiatric diagnoses, and satisfaction. Obes Surg. 1997;7:471-7.

36. Fontanella BJB, Ricas J, Turato ER. Amostragem por saturação em pesquisas qualitativas em saúde: contribuições teóricas. Cad Saúde Pública. 2008;24:17-27.

37. Bardin L. Análise de conteúdo. 5a ed. Lisboa: Edições 70; 2009.

38. van Hout GC, Boekestein P, Fortuin FA, Pelle AJ, van Heck GL. Psychosocial functioning following bariatric surgery. Obes Surg. 2006;16:787-94.

39. van Hout GC, Fortuin FA, Pelle AJ, van Heck GL. Psychosocial functioning, personality, and body image following vertical banded gastroplasty. Obes Surg. 2008;18:115-20. Epub 2007 Dec 15.

40. Magdaleno R Jr, Chaim EA, Turato ER. Understanding the life experiences of Brazilian women after bariatric surgery: a qualitative study. Obes Surg. 2010;20:1086-9. Epub 2008 Oct 2.

41. Magdaleno R Jr, Chaim EA, Pareja JC, Turato ER. The psychology of bariatric patient: what replaces obesity? A qualitative research with Brazilian women. Obes Surg. 2011;21:336-9. Epub 2009 Mar 21.
42. de Zwaan M, Lancaster KL, Mitchell JE, Howell LM, Monson $N$, Roerig JL, et al. Health-related quality of life in morbidly obese patients: effect of gastric bypass surgery. Obes Surg. 2002; $12: 773-80$.

43. Maddi SR, Fox SR, Khoshaba DM, Harvey RH, Lu JL, Persico M. Reduction in psychopathology following bariatric surgery for morbid obesity. Obes Surg. 2001;11:680-5.

44. Curtis C, Davis C. A qualitative study of binge eating and obesity from an addiction perspective. Eat Disord. 2014;22:19-32.

45. Eichen DM, Lent MR, Goldbacher E, Foster GD. Exploration of "food addiction" in overweight and obese treatment-seeking adults. Appetite. 2013;67:22-4. Epub 2013 Mar 25.

46. Pretlow RA. Addiction to highly pleasurable food as a cause of the childhood obesity epidemic: a qualitative Internet study. Eat Disord. 2011;19:295-307.

47. Sinha $R$, Jastreboff $A M$. Stress as a common risk factor for obesity and addiction. Biol Psychiatry. 2013;73:827-35. Epub 2013 Mar 26.

\section{Correspondence:}

Ataliba de Carvalho Júnior

Departamento de Psicologia e Psiquiatria, Faculdade de Medicina, Universidade Estadual de Campinas (UNICAMP)

Rua Dona Rosa de Gusmão, 412

13073-141 - Campinas, SP - Brazil

Tel./Fax: +55 (19) 9269.8247, +55 (19) 3243.1374

E-mail: atalibade@uol.com.br 